\title{
THE EFFECT OF SURVEY, QUESTION, READ, RECITE, AND REVIEW (SQ3R) TEACHING METHOD AND READING INTEREST TOWARD READING COMPREHENSIONS OF CHILDREN STORIES ABILITY (EXPERIMEN RESEARCH IN THE $5^{\text {th }}$ GRADE OF ELEMENTARY SCHOOL AT LAWEYAN DISTRICTS SURAKARTA IN THE SCHOOL YEAR 2017/2018
}

\author{
Miftakhul Husna, St. Y. Slamet, Jenny Indrastoeti Siti Poerwanti \\ Universtitas Sebelas Maret \\ mitahusna41@gmail.com
}

Article History

accepted 09/07/2018

approved 01/08/2018

published 17/09/2018

Keywords

SQ3R, CIRC, minat baca, kemampuan membaca

pemahaman

\begin{abstract}
The purpose of this research 1) The difference of reading comprehensions of children stories ability that taught by SQ3R teaching method within CIRC teaching method, 2) The difference of reading comprehensions of children stories ability between students who had high interest in reading and students who had low interest in reading, 3) The interaction between teaching method and reading interes. This research used quasi experimental method with randomized contract group pretest-postest used factorial $2 \times 2$ design. The result of this research showed that: 1) There was the difference of reading comprehensions of children stories ability that teach SQ3R teaching method and students who were taught by CIRC teaching method 2 ) there was the difference of between students who had high interest in reading and students who had low interest in reading 3) There was interaction between teaching method and reading interest.
\end{abstract}

Social, Humanities, and Education Studies (SHEs): Conference Series https://jurnal.uns.ac.id/shes

p-ISSN 2620-9284

e-ISSN 2620-9292 


\section{PENDAHULUAN}

Belajar bahasa sama halnya dengan belajar bekomunikasi. Pembelajaran Bahasa Indonesia di Sekolah Dasar diarahkan untuk dapat meningkatkan kemampuan peserta didik baik lisan maupun tulisan. Peningkatan kemampuan lisan peserta didik di kelas $\mathrm{V}$ dalam mata pelajaran Bahasa Indonesia bisa ditingkatkan dengan berbagai cara, salah satunya kegiatan membaca. Membaca adalah sebuah proses yang dilakukan pembaca untuk memperoleh pesan, yang disampaikan dari seorang penulis melalui media kata-kata bahasa tulis (Tarigan, 2008: 7). Kegiatan membaca harus ditunjang dengan kemampuan membaca, karena tanpa memiliki kemampuan membaca, seseorang sulit untuk memahami suatu bacaan. Pemahaman ini yang selanjutnya digunakan untuk berkomunikasi dengan orang lain. Adapun membaca yang baik adalah membaca yang tidak hanya sekadar membaca saja tetapi juga mengetahui maksud dan dapat memahami isi bacaan.

Kegiatan membaca di kelas V SD berkaitan dengan membaca cerita anak. Hal ini sesuai dengan Kurikulum Standar Isi 2006, standar kompetensi awal yang dituntut pada siswa kelas V SD adalah memahami teks dengan membaca sekilas, membaca memindai, dan membaca cerita anak. Kemampuan memahami cerita anak merupakan suatu daya atau potensi yang dilakukan dari latihan dan membutuhkan sebuah konsentrasi khusus agar dapat memahami isi cerita anak tersebut. Kenyataanya dilapangan siswa belum mampu memahami bacaan dengan baik. Siswa dapat membaca dengan lancar tetapi belum mampu memahami isi bacaan khususnya cerita anak. Hal ini dibuktikan dengan penelitian yang dilakukan oleh Wulandari (2014) bahwa terdapat masalah untuk kemampuan membaca pemahaman cerita anak yang nilainya masih rendah dibawah KKM.

Metode pembelajaran mempunyai peran yang sangat penting, karena dengan metode pembelajaran peserta didik dapat lebih mudah menangkap informasi dari guru. Metode merupakan sebuah cara menyampaikan materi pelajaran kepada siswa (Jihad \& Haris 2013: 24). Apabila guru mampu memilih dan menggunakan metode pembelajaran yang inovatif dan kreatif, maka peserta didik dapat memahami konsep yang diberikan oleh guru sehingga akan diikuti dengan hasil belajar yang maksimal. Pembelajaran membaca pemahaman cerita anak ini dapat menggunakan metode, salah satunya adalah metode survey, question, read, recite, and review (SQ3R). Menurut Asiri (2017) dalam Asian Journal of Education Research yang menyatakan bahwa SQ3R is a reading comprehension strategy devised for reading textbook and assignments for diverse learners. Pembelajaran ini adalah salah satu metode yang bisa digunakan untuk mengatasi permasalahan kurangnya kemampuan membaca pemahaman pada cerita anak. Metode ini mudah digunakan karena langkahnya yang sistematis dan mempertahankan daya ingat karena terdapat tahap recite dan review. Selain menggunakan metode survey, question, read, recite and review (SQ3R) metode lain yang bisa digunakan untuk memahami cerita anak adalah cooperative integrated reading and composition ( $\mathrm{CIRC}$ ). Metode ini adalah metode khusus untuk pembelajaran Bahasa, dan jarang digunakan dalam pembelajaran fisika, matematika, dll. Menurut Darmayanti (2014) dalam Jurnal Ethical Lingua menyatakan bahwa CIRC adalah a cooperative method that introduces the latest techniques of practical training curriculum on teaching reading. Metode CIRC ini memiliki keunggulan sangat tepat untuk meningkatkan keterampilan siswa dalam menyelesaikan suatu masalah. Dominasi guru dalam pembelajaran sangat sedikit, sehingga melatih kekreatifitasan anak didik dalam menyelesaikan tugas dari guru secara berkelompok. Pembelajaran berkelompok ini membuat siswa memiliki rasa tanggung jawa yang tinggi terhadap kelompoknya. 
Pembelajaran Bahasa Indonesia di kelas $\mathrm{V}$ materi pemahaman cerita anak, keaktifan siswa sangatlah penting. Tinggi rendahnya keaktifan siswa ditentukan oleh minat dari dalam diri, khususnya minat baca. Pembelajaran ini membutuhkan keterlibatan dari seorang peserta didik dan ketertarikannya untuk membaca. Menurut Sandjaya (2014: 71) Minat (interest) yaitu kecenderungan individu untuk melakukan sesuatu perbuatan. Seseorang yang memiliki minat terhadap hal akan cenderung memberikan suatu perhatian yang lebih pada hal atau sesuatu tersebut. Ketika seorang individu harus dituntut untuk membaca, maka minat baca yang harus timbul dalam diri. Minat baca merupakan minat yang harus ada atau melekat pada diri sesorang ketika dia harus memahami suatu bacaan, tanpa adanya minat baca tersebut seseorang peserta didik tidak dapat memahami bacaan tersebut dengan baik. Minat baca adalah dorongan untuk memahami kata demi kata dan misi terkandung dalam suatu teks bacaan, sehingga pembaca dapat memahami hal-hal yang dituangkan dalam membaca (Dalman 2014: 141). Menurut Triatma (2016) minat baca rendah disebabkan karena mahalnya beberapa buku, terbatasnya fasilitas perpustakaan. Semakin besar minat membacanya maka semakin besar pula pemahaman dalam kemampuan memahami cerita anak dan semakin kecil minat membaca seseorang maka semakin kecil pemahaman peserta didik terhadap kemampuan memahami cerita anak. Berdasarkan atas berbagai pertimbangan tersebut, penulis mengangkat judul dalam penelitian ini adalah PENGARUH METODE PEMBELAJARAN SURVEY, QUESTIONS, READ, RECITE, AND REVIEW (SQ3R) DAN MINAT BACA TERHADAP KEMAMPUAN MEMBACA PEMAHAMAN CERITA ANAK (Penelitian Eksperimen Pada Siswa Kelas V SD Se-Kecamatan Laweyan Tahun Ajaran 2017/2018).

Rumusan masalah pada penelitian ini adalah 1)Apakah ada perbedaan kemampuan membaca pemahaman cerita anak antara siswa yang diajarkan dengan metode pembelajaran survey, questions, read, recite, and review (SQ3R) dan cooperative integrated reading and composition (CIRC). Jika ada perbedaan manakah yang hasilnya lebih baik? 2) Apakah ada perbedaan kemampuan membaca pemahaman cerita anak antara siswa yang memiliki minat baca tinggi dan siswa yang memiliki minat baca rendah? Jika ada perbedaan, manakah yang lebih baik? 3) Apakah ada interaksi antara metode pembelajaran dan minat baca terhadap kemampuan membaca pemahaman cerita anak?

Tujuan dari penelitian ini adalah 1) Untuk mengetahui perbedaan kemampuan membaca pemahaman cerita anak antara siswa yang diajarkan dengan metode pembelajaran survey, questions, read, recite, and review (SQ3R) dan siswa yang diajar dengan metode pembelajaran cooperative integrated reading and composition (CIRC), 2) Untuk mengetahui perbedaan kemampuan membaca pemahaman cerita anak antara siswa yang memiliki minat baca tinggi dan siswa yang memiliki minat baca rendah.3) Mengetahui interaksi antara metode pembelajaran dan minat baca terhadap kemampuan membaca pemahaman cerita anak.

\section{METODE}

Penelitian ini dilaksanakan di SD Negeri Setono sebagai kelas ekperimen, dan SD Bratan 2 sebagai kelas kontrol. Metode yang digunakan dalam penelitian ini menggunakan metode eksperimental semu (quasi experimental). Desain penelitian ini menggunakan rancangan randomixed contract pretest-postest desain dengan factorial $2 \times 2$. Populasi dalam penelitian ini adalah seluruh siswa kelas V Sekolah Dasar di Kecamatan Laweyan Kota Surakarta. Sampel yang digunakan pada penelitian ini adalah SD Negeri Setono sebagai kelas Eksperimen dan SD Bratan 2 sebagai kelas kontrol. Teknik pengumpulan data yang digunakan dalam penelitian ini ada dua macam, yaitu tes dan nontes. Instrumen penilain dalam penelitian 
ini adalah lembar tes kemampuan membaca pemahaman cerita anak dan lembar anket minat baca siswa.

Pada penelitian eksperimen ini menggunakan teknik cluster random sampling. Teknik sampling ini digunakan untuk menetukan sampel bila obyek yang akan diteliti atau sumber data sangat luas. Uji validitas dalam tes kemampuan membaca pemahaman cerita anak menggunakan expert judgement, sedangkan untuk angket minat baca menggunakan product moment. Reliabilitas dalam tes kemampuan membaca pemahaman menggunakan KR-20 dan angket minat baca menggunakan perhitungan alpha cronbach. Teknik analisis data yang digunakan yaitu Analisis Variansi Dua Jalan.

\section{HASIL DAN PEMBAHASAN}

Sebelum uji analisis data terlebih dahulu dilakukan uji prasyarat analisis yaitu uji normalitas dan uji homogenitas, sedangkan untuk menguji keseimbangan kemampuan awal antara kelompok eksperimen dan kelompok kontrol menggunakan uji-t. Uji keseimbangan kemampuan awal kedua sampel sama atau tidak. Uji keseimbanagn ini diambil dari nilai pretest.

Tabel 1. Rata-rata dan variansi data pretest

\begin{tabular}{cccc}
\hline Kelompok & Jumlah & $\mathbf{X}$ & $\mathbf{S}$ \\
Eksperimen & 36 & 70,27 & 14,16 \\
Control & 39 & 65,12 & 12,7 \\
\hline
\end{tabular}

Berdasarkan tabel 1. diketahui bahwa kelompok eksperimen memperoleh rata-rata skor 70,27 dengan standar deviasi sebesar 14,16; sedangkan untuk kelompok kontrol memperoleh rata-rata skor 65,12 dengan standar deviasi sebesar 12,7 .

Tabel 2. Statstik uji normalitas Data Pretest

\begin{tabular}{cccc}
\hline Sampel & $\mathbf{L}_{\text {maks }}$ & $\mathbf{L}_{\text {tabel }}$ & Keputusan uji \\
Eksperimen & 0,103 & 0,147 & $\mathrm{H}_{\circ}$ diterima \\
Control & 0,087 & 0,141 & $\mathrm{H}_{0}$ diterima \\
\hline
\end{tabular}

Berdasarkan dari tabel 2 diketahui harga Lhitung untuk masing-masing sampel tidak melebihi harga $L_{\text {tabel }}$ sehingga $\mathrm{H}_{0}$ diterima yang berarti sampel berasal dari populasi yang berdistribusi normal.

Hasil uji homogenitas dengan uji Bartlett dengan statistik uji Chi-kuadrat (x2) dan tingkat signifikansi 0,05 diperoleh nilai statistik uji dari kelompok eksperimen dan kontrol adalah $\mathrm{X} 2$ hitung $=0,405$ dan $\mathrm{X} 2$ tabel adalah 3,841. Hasil perhitungan Uji Chi-kuadrat diperoleh

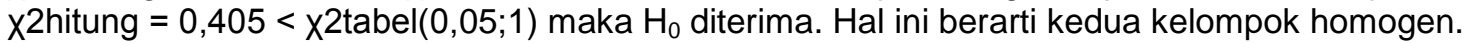

Sampel penelitian berasal dari populasi yang berdistribusi normal dan variansinya homogen maka selanjutnya dilakukan uji-t. Penelitian ini memiliki jumlah siswa (n) dari masingmasing kelas berbeda. Jika jumlah (n) berbeda maka rumus uji-t. Hasil uji keseimbangan dengan uji-t diperoleh thitung $=1,659$ Berdasarkan perhitungan, thitung $=1,659 \notin \mathrm{DK}=\{\mathrm{t} \mid \mathrm{t}<$ $-3,84$ atau $t>3,84\}$ atau $t_{\text {hitung }}$ bukan anggota daerah kritis, maka $\mathrm{H}_{0}$ diterima. Oleh karena itu, dapat disimpulkan bahwa kemampuan awal kedua sampel penelitian tersebut dalam keadaan seimbang atau kedua sampel penelitian mempunyai kemampuan awal yang sama.

Tabel 3. Statistik Uji Normalitas

\begin{tabular}{cccl}
\hline Sumber & $\mathbf{L}_{\text {maks }}$ & $\mathbf{L}_{\text {tabel }}$ & Keputusan \\
Kelompok Eksperimen & 0,078 & 0,147 & Ho diterima \\
Kelompok Kontrol & 0,101 & 0,141 & Ho diterima \\
Minat Baca Tinggi & 0,083 & 0,124 & Ho diterima \\
Minat Baca Rendah & 0,119 & 0,181 & Ho diterima \\
\hline
\end{tabular}

Berdasarakan tabel 3. dapat dilihat bahwa harga $L=\operatorname{maks}\{|F(z i)-S(z i)|\}$ pada kelompok eksperimen, kelompok kontrol, minat baca tinggi serta minat baca rendah tidak melebihi harga Ltabel sehingga $\mathrm{H}_{0}$ diterima. Hal ini berarti sampel penelitian berasal dari populasi yang berdistribusi normal. 
Tabel 4. Hasil Analisis Uji Hipotesis

\begin{tabular}{cccc}
\hline Sumber & $\mathbf{X}^{2}$ & $\mathbf{X}^{2}$ tabel & $\begin{array}{l}\text { Keputusan } \\
\text { Ho diterima }\end{array}$ \\
$\begin{array}{c}\text { Kelompok Eksperimen } \\
\text { dan Kontrol }\end{array}$ & 1,928 & 3,841 & Ho diterima \\
$\begin{array}{c}\text { Minat Baca Tinggi dan } \\
\text { rendah }\end{array}$ & 2,557 & 3,841 & Ho diterima \\
Antar Sel & 2,249 & 7,841 &
\end{tabular}

Berdasarkan tabel data hasil analisis uji homogentias pada Tabel 4 diperoleh harga $x^{2}$ hitung pada kelompok eksperimen dan kelompok kontrol, minat baca tinggi dan minat baca rendah, serta antar sel tidak melebihi harga $X_{\text {tabel }}$ sehingga $\mathrm{H}_{0}$ diterima. Hal ini berarti data ketiga kelompok adalah homogeny.

Pengujian hipotesis penelitian digunakan Analisis Variansi Dua Jalan dengan sel tak sama pada tingkat signifikansi $\alpha=5 \%$. Berikut ini adalah hasil perhitungan analisis variansi dua jalan dengan sel tak sama yang terangkum pada Tabel 5 berikut:

Tests of Between-Subject Effects

Dependent Variable: kemampuan memahami cerita anak

\begin{tabular}{|c|c|c|c|c|c|}
\hline Source & $\begin{array}{c}\text { Type III Sum } \\
\text { of Squares }\end{array}$ & Df & Mean Square & F & Sig. \\
\hline Corrected Model & $6103.167^{\text {a }}$ & 3 & 2034.389 & 44.920 & .000 \\
Intercept & 343075.550 & 1 & 343075.550 & 7575.296 & .000 \\
Metodepembelajaran & 2904.154 & 1 & 2904.154 & 64.125 & .000 \\
Minatbaca & 3303.852 & 1 & 3303.852 & 72.951 & .000 \\
metodepembelajaran * & 432.833 & 1 & 432.833 & 9.557 & .003 \\
minatbaca & 3215.500 & 71 & 45.289 & & \\
Error & 430444.000 & 75 & & & \\
Total & 9318.667 & 74 & & & \\
Corrected Total & & & &
\end{tabular}

a. $\mathrm{R}$ Squared $=.655$ (Adjusted R Squared $=.640$ )

Hasil penelitian menunjukan bahwa (1) ada perbedaan kemampuan membaca pemahaman antara siswa yang diajar dengan metode pembelajaran SQ3R dan siswa yang diajar dengan metode pembelajaran CIRC, yang ditunjukan dengan taraf signifikasi ( $\alpha$ ) $0,00<0,05$; (2) ada perbedaan kemampuan membaca pemahaman antara siswa yang memiliki minat baca tinggi dan rendah, yang ditunjukan dengan taraf signifikasi ( $\alpha$ ) $0,00<0,05$; (3) terdapat interaksi antara metode pembelajaran dan minat baca, yang ditunjukkan dengan taraf signifikasi $(\alpha) 0,003<0,05$

Pada penelitian ini, hasil statistic uji hipotesis menggunakan analisis variasi dua jalan dengan sel tak sama diperoleh $\mathrm{F}_{\mathrm{A}}, \mathrm{F}_{\mathrm{B}}, \mathrm{F}_{\mathrm{AXB}}$ menunjuukan adanya perbedaan yang signifikan sehingga perlu dilakukan uji lanjut pasca anava dengan uji schefee

Hipotesis pertama dan kedua tidak perlu dilakukan uji lanjut karena hanya mempunyai dua kategori. Selanjutnya, untuk mengetahui manakah hasilnya yang lebih baik cukup dengan membandingkan jumlah rataan marginal dari masing-masing variabel. Uji hipotesis ketiga perlu dilakukan uji lanjut untuk mengetahui manakah yang lebih baik. Hasil rata-rata marginal setiap sel dapat dilihat dalam tabel 6 berikut.

Tabel 6. Rata-rata marginal masing-masing tes

\begin{tabular}{llll}
\hline $\begin{array}{l}\text { Metode } \\
\text { pembelajaran }\end{array}$ & Tinggi $\left(B_{1}\right)$ & $\begin{array}{c}\text { Minat baca } \\
\text { Rendah }\left(B_{2}\right)\end{array}$ & Rataan marginal \\
\hline SQ3R $\left(A_{1}\right)$ & 83,79 & 74,67 & 79,23 \\
CIRC $\left(A_{2}\right)$ & 74,25 & 56,17 & 65,21 \\
Rataan Marginal & 79,02 & 65,42 & \\
\hline
\end{tabular}


Hipotesis pertama $\left(\mathrm{H}_{\mathrm{OA}}\right)$ ditolak berarti ada perbedaan yang signifikan kemampuan membaca pemahaman cerita anak antara siswa yang diajar dengan metode pembelajaran SQ3R dan CIRC. Untuk mengetahui yang lebih baik antara metode tersebut dengan membandingkan besarnya rata-rata dari masing-masing metode pembelajaran. Rata-rata marginal baris $A 1=79,23$ dan rataan marginal baris $A 2=65,21$. Hal ini diperkuat oleh Firdaus (2012) dalam jurnalnya bahwa siswa yang diajar dengan survey, question, read, recite, and review (SQ3R) dapat memberikan dampak yang positif terhadap kemampuan membaca pemahaman cerita anak.

Hipotesis kedua $\left(\mathrm{H}_{\mathrm{OB}}\right)$ ditolak, yang berarti ada perbedaan kemampuan membaca pemahaman cerita anak yang memiliki minat baca tinggi dan rendah. Rata-rata marginal pada kolom B1 $=79,02>$ pada kolom B2 $=65,42$ hal ini menunjukkan bahwa siswa yang memiliki minat baca tinggi reratanya lebih tinggi dari pada siswa yang memiliki minat baca rendah. Hal ini diperkuat oleh Al-Nafisah dan Al-Shorman (2012) bahwa minat membaca individu dianggap menjadi factor penentu apa yang akan dibaca oleh siswa.

Hipotesis ketiga $\left(\mathrm{H}_{\mathrm{OAXB}}\right)$ ditolak, hal ini berarti terdapat interaksi antara metode pembelajaran dan minat baca terhadap kemampuan membaca pemahaman cerita anak. Hipotesis ketiga $\left(\mathrm{H}_{\mathrm{OAXB}}\right)$ ditolak maka perlu dilakukan uji lanjut. Pasca anava (uji komparasi ganda) antar sel pada baris atau kolom yang sama. Untuk pengujian ini menggunakan uji schefee.

Tabel 7. Uji scheffe

\begin{tabular}{|l|l|l|l|}
\hline Komparasi & $F_{\text {hit }}$ & $F_{\text {tabel }}$ & Keputusan \\
\hline$A_{1} B-A_{2} B_{1}$ & 25,56 & 3,45 & Ditolak \\
\hline$A_{1} B_{2}-A_{2} B_{2}$ & 45,6 & 3,45 & Ditolak \\
\hline$A_{1} B_{1}-A_{1} B_{2}$ & 21,01 & 3,45 & Ditolak \\
\hline$A_{2} B_{1}-A_{2} B_{2}$ & 60,1 & 3,45 & Ditolak \\
\hline
\end{tabular}

Berdasarkan tabel 7. Hasil anava dua jalan diketahui bahwa a) Komparasi rataan antar sel $A_{1} B_{1}-A_{2} B_{1}$ (Ho ditolak). Hal ini berarti kemampuan memahami cerita anak yang diberikan metode pembelajaran SQ3R dan memiliki minat baca tinggi lebih baik daripada siswa yang diajar dengan metode pembelajaran $\mathrm{CIRC}$ dan memiliki minat baca tinggi, b) Komparasi rataan antar sel $A_{1} B_{2}-A_{2} B_{2}$ (Ho ditolak). Hal ini berarti kemampuan memahami cerita anak yang diberikan metode pembelajaran SQ3R dan memiliki minat baca rendah lebih baik daripada siswa yang diajar dengan metode pembelajaran $\mathrm{CIRC}$ dan memiliki minat baca rendah, $\mathrm{C}$ ) Komparasi rataan antar sel $A_{1} B_{1}-A_{1} B_{2}$ (Ho ditolak). Hal ini berarti kemampuan memahami cerita anak yang diberikan metode pembelajaran SQ3R dan memiliki minat baca tinggi lebih baik daripada siswa yang diajar dengan metode pembelajaran SQ3R) dan memiliki minat baca rendah, d) Komparasi rataan antar sel $\mathrm{A}_{2} \mathrm{~B}_{1}-\mathrm{A}_{2} \mathrm{~B}_{2}$ (Ho ditolak). Hal ini berarti kemampuan memahami cerita anak yang diberikan metode pembelajaran CIRC dan memiliki minat baca tinggi lebih baik daripada siswa yang diajar dengan metode pembelajaran CIRC dan memiliki minat baca rendah

\section{SIMPULAN}

Berdasarkan teori dan hasil analisis data, dapat ditarik kesimpulan, yaitu 1) Ada perbedaan kemampuan membaca pemahaman cerita anak antara siswa yang diajar dengan metode SQ3R dengan siswa yang diajar dengan metode pembelajaran CIRC, dengan taraf signifikasi $0,00<0,05$. 2) Ada perbedaan kemampuan membaca pemahaman cerita anak antara siswa yang memiliki minat baca tinggi dan rendah, dengan taraf signifikasi $0,00<0,05$. 3) Terdapat interaksi antara metode pembelajaran dan minat baca terhadap kemampuan membaca pemahaman cerita anak dengan taraf signifikasi $0,003<0,05$. Berdasarkan uji lanjut pasca anava menggunakan uji schefee diperoleh keputusan 1) siswa yang diberikan metode pembelajaran SQ3R dan mempunyai minat baca tinggi lebih baik daripada siswa yang diajar dengan metode pembelajaran CIRC dan mempunyai minat baca tinggi,2) siswa yang diberikan 
metode pembelajaran SQ3R dan memiliki minat baca rendah lebih baik daripada siswa yang diajar dengan metode pembelajaran CIRC dan memiliki minat baca rendah, 3) siswa yang diberikan metode pembelajaran SQ3R dan memiliki minat baca tinggi lebih baik daripada siswa yang diajar dengan metode pembelajaran SQ3R dan memiliki minat baca rendah, 4) siswa yang diberikan metode pembelajaran CIRC dan memiliki minat baca tinggi lebih baik daripada siswa yang diajar dengan metode pembelajaran $\mathrm{CIRC}$ dan memiliki minat baca rendah.

\section{DAFTAR PUSTAKA}

Al-Nafisah \& Al-Shorman. (2011). Saudia EFL student's reading interest. Journal of King Sand University-Languages and Translation. www.sciendirect.com

Asiri Ahmad. 2017. The Effectivitiness of Using SQ3R to Teach Reading Skills. Asian Journals of Educational Research Vol, 5 No, 1 (1-5). Diunduh pada tanggal 5 Januari 2018 dalam www.multidisciplinaryjournals.com

Dalman. 2013. Keterampilan Membaca. Jakarta: Rajawali Press.

Haris, Abdul \& Jihad, Asep. (2013). Evaluasi Pembelajaran. Yogyakarta: Multi Pressindo

Rahim, F. 2008. Pengajaran Membaca di Sekolah Dasar. Jakarta: Sinar Grafika

Tarigan H.G. 2008. Membaca. Bandung: Percetakan Angkasa.

Triatma, Ilham Nur (2016). Minat Baca pada Siswa Kelas VI Sekolah Dasar Negeri Delegan 2 Prambanan Sleman Yogyakarta. E-Journal Prodi Teknologi Pendidikan Vol V. Nomor 6 Tahun 2016

Wulandari, R.D. 2014. Pengaruh Strategi Pembelajaran Survey, Question, Read, Recite, and Review (SQ3R) Terhadap Kemampuan Membaca Pemahaman Ditinjau Dari Minat Baca Siswa Kelas V SD Negeri Se-Gugus Ki Hajar Dewantoro Kecamatan Colomadu Tahun Pelajaran 2013/2014. Skripsi: Universitas Sebelas Maret. 